\title{
RATIO WOBEC SZTUKI, TAKŻE SAKRALNEJ
}

\section{WPROWADZENIE}

Łaciński wyraz ratio ma wiele odniesień, zabarwień, znaczeń. Najwięcej zależy od kontekstu i zakresu zainteresowania. Zawsze jednak odnosi się do sfery intelektualnej. Podstawowym słowem, które ma różne zakresy znaczeniowe jest - „obliczenie”. Dotyczy więc najpierw sfery finansowej, rachunkowej'. Jest też poszukiwaniem uzasadnień, rozważaniem argumentów ${ }^{2}$. Na co dzień funkcjonuje w zwrotach „mam rację”, „bronię swoich racji”. Etymologiczny związek odnajdujemy nawet w stwierdzeniu dotyczącym relacji ogólnopaństwowych czy dyplomatycznych: „swoją postawą bronię racji stanu”. Nas najbardziej interesuje opcja myślenia, zastanowienia się, refleksji ${ }^{3}$. Także cała gama kwestii związanych z lokalizacją, skalą, wielkością, pojemnością, integralnym programem samego obiektu kultu i jego otoczenia, wszystko to wymaga spójności, konsekwencji, ale też logiki połączonej z rozsądkiem, rozwagą. Dzieło sztuki skupia naszą uwagę nie tylko na samej formie, lecz także jego przeznaczeniu. Niezbędna jest tu postawa roztropnej odpowiedzialności także we wszystkich fazach kształtowania konkretnego dzieła sakralnego. Jakby podświadomie uwaga nasza kieruje się ku

\footnotetext{
1 „Ratio constat” - rachunek się zgadza; ,rationem reddere”- zdać rachunek.

2 „Rationem habere alcis rei” - uwzględniać, mieć wzgląd na coś.

3 „Ratione” - rozsądnie, metodycznie, teoria, twierdzenie, zasada, pogląd, możliwość; „,secundum rationem”- stosownie, należycie; „omni ratione” w każdy sposób.
} 
rozumnym decyzjom i działaniom. Dodajmy, znaczenie motywacji przybliżania i obecności w świecie, w życiu publicznym całej sfery sacrum. Nie dlatego, że jest popularne czy modne, że budzi poklask mas czy poparcie wpływowego lobby. To powinno być powołaniem, zadaniem ewangelizacyjnym i zaangażowaniem żywego Kościoła.

Jakże istotny jest kod językowy oraz interpretacja faktów, zjawisk oraz prawd wiary, w tym tych, które zawarte są w chrześcijańskim Credo. I tak, Leszek Kołakowski w publikacji, która ukazała się po jego śmierci, z jednej strony akceptuje historyczność osoby Jezusa Chrystusa i wiele przesłań Ewangelii, zarazem jednak wszystko, co przerasta percepcję intelektualną i zmysłową, w tym cuda, obecność Eucharystyczną, rzeczy ostateczne, określa mianem mitu. Słusznie np. stwierdza, że relacje i obecność chrześcijaństwa w świecie jest ważna i ma sens o tyle, o ile jest ,trwaniem ponadczasowego w czasowym”, a także, jak bardzo istotna jest „obecność tradycji chrześcijańskiej w świeckim życiu publicznym" ${ }^{4}$. W innym miejscu przypomina jakże kontrowersyjne tezy modernizmu francuskiego czy protestanckiej teologii liberalnej: „raz napisany tekst się nie zmienia, ale jego percepcja nieuchronnie zmienia się wraz z przemianami kultury, wrażliwości, wiedzy; w konsekwencji ewoluuje też znaczenie tekstu. [...] Wszystkie formuły wiary, dogmaty i symbole są tylko historyczne, a więc z konieczności z biegiem historii tracą żywotność i stają się anachroniczne"5.

Warto zauważyć, że właśnie relatywizm jest zjawiskiem, które coraz bardziej wkrada się do wielu dziedzin życia i kultury, nauki i sztuki. Dotyka też różnych relacji wokół liturgii czy teologii. Od lat ubolewał nad tym Joseph Ratzinger. Jakże ważny dokument (podpisany 6 sierpnia 2000 roku) wyszedł spod jego ręki, jako Prefekta Kongregacji Nauki Wiary. Chodzi o Deklarację Dominus Iesus, której był on autorem ${ }^{6}$. W różnych swych tekstach wykazuje, że

${ }^{4}$ L. K oła k ow s k i, Jezus ośmieszony. Esej apologetyczny i sceptyczny. Wydawnictwo Znak, Kraków 2014, s. 35, 47.

5 Ta m że, s. 76, 78.

${ }^{6}$ Kongrega cj a N a u i W i a r y, Deklaracja „Dominus Iesus“. Tekst i komentarze, Wprowadzenie: kard. Joseph Ratzinger, Pallottinum, Poznań 2006, ss. 226. 
nowoczesna racjonalność (sic!) doprowadza do całkowitej negacji wiary i odpersonalizowania Boga. Kult nauki w postaci racjonalizmu scjentystycznego doprowadza wręcz do traktowania Go li tylko jako idei, a w końcu do całkowitego odrzucenia, co Heidegger nazywa „odbóstwieniem świata”. Jednocześnie należy zauważyć, że ludzie Kościoła, cenieni profesorowie dość rozbieżnie interpretują wiele kwestii, które są pokłosiem podejścia do litery II Soboru Watykańskiego 7 . Toczy się kulturowy i umysłowy zamęt, czego konsekwencją jest utrata religijnego dziedzictwa. Europę dotknęła amnezja wobec własnych korzeni chrześcijańskich. Pewnym intelektualnym paradoksem jest interpretacja trzech odrębnych opisów powołanej flagi Rady Europy: heraldycznego, geometrycznego i symbolicznego. Znamienne, że zarówno data powołania flagi przez Komitet Ministrów, czyli 8 grudnia 1955, jak i jej lazurowy kolor oraz 12 złotych gwiazd, wskazują na zaakcentowanie jej nawiązania do Niepokalanego Poczęcia Maryi oraz odniesień do znamiennych kilku objawień. Intrygujące są cytaty ówczesnych artykułów, które do tego nawiązują. Zrazem pojawiają się teksty, które próbują ów kontekst maryjny flagi europejskiej odrzucić. Jakże interesujące są argumenty, niestety nie zawsze racjonalne, obydwu stron ${ }^{8}$. Zapewne także w tym kontekście można by zacytować znane przysłowie: „Gdy rozum śpi, budzą się demony”.

Przez całe wieki w historii chrześcijaństwa zjawiskiem groźnym jest fałsz i błąd. Świadomie i celowo wypaczana jest nauka Kościoła, jego dogmaty czy kult. Przejawem tego są pojawiające się różne herezje. Św. Wincenty z Lerynu (V wiek) przestrzega przed krzewicielami „,bezbożnych nowinek”, którzy wabią „,bystrością, biegłością i tak zwaną wiedzą" a zarazem kłamiąc, wprowadzają zamęt

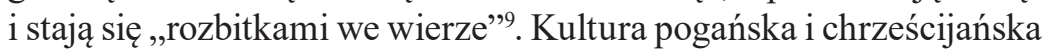

${ }^{7}$ G. M a y, Die andere Hierarchie, Verlag Franz Schmitt, Siegburg 1997, s. 71$-90,107-111$.

${ }^{8} \mathrm{~K}$. K ow a $1 \mathrm{ski}$, Europa: mity, modele, symbole, Międzynarodowe Centrum Kultury, Kraków 2002, s. 145-166.

9 Wincenty z Lerynu, Pamiętnik Commonitorium, Uniwersytet im. Adama Mickiewicza, Poznań 2002 (reprint z 1928 roku), s. 48, 40: „Zaprawdę błędną nazwę noszą nauki heretyków: nieuctwo podaje się za naukowość, mglistość za 
wzajemnie się przenikały i wreszcie doszły „do fazy, w której religia będzie współistnieć z życiem, a poszukiwanie Boga będzie rzucać swój cień na wszelką ludzką działalność"10. Zauważmy, że to samo zjawisko inaczej przedstawi agnostyk, inaczej wierzący czy wreszcie ateista. W tym krótkim cytacie, my chrześcijanie dostrzeglibyśmy, że owa teocentryczna opcja jest raczej rzucaniem światła, natomiast dla autora-agnostyka jest to rzucanie cienia na ludzką aktywność.

\section{W POSZUKIWANIU SENSU}

Analizując jakiekolwiek dzieło sztuki, dostrzegamy jego treść pod kątem tematu oraz zawartej w mim „wypowiedzi ideowej”. Jedno i drugie wynika z przeżyć, obserwacji i stanu ducha artysty, ale również jego życia umysłowego. Jest jednocześnie ,wyrazem jakiegoś poglądu na świat, jakichś treści świadomie przekazywanych i jakichś treści nie uświadamianych przez artystę, tkwiących w nim jako człowieku epoki, która dzieło wydała", jak trafnie zauważa Jan Białostocki ${ }^{11}$. Jest ono więc zarówno owocem swego czasu, jak i ten swój czas ubogaca intelektualnie, artystycznie, a także teologicznie.

Spośród licznej literatury przedmiotu, pragnę zwrócić uwagę na niewielką książkę, która w przystępny sposób przybliża czytelnikowi kilkadziesiąt obrazów różnych epok. „Nie narzuca się też tu interpretacji, czasem jedynie coś podpowiada. Celem tych krótkich tekstów, poświęconych zawsze jednemu dziełu sztuki, jest głównie rozbudzenie 'ciekawości oka', pokazanie, jak wiele można zobaczyć w obrazie, gdy poświęcimy mu trochę czasu i uwagi"'12.

jasność, mroki za światło”; s. 64: „Słusznie na nas wina spada, jeżeli milczeniem sprzyjamy błędowi. Więc karcić takich trzeba; nie dozwalać im swobodnie wedle widzimisię mówić".

10 E.R. D o d d s, Pogaństwo i chrześcijaństwo w epoce niepokoju, Wydawnictwo Homini S.C., Kraków 2004, s. 98.

11 J. B i ał o s to c ki, Sztuka i myśl humanistyczna. Studia z dziejów sztuki i myśli o sztuce, Państwowy Instytut Wydawniczy, Warszawa 1966, s. 155.

${ }_{12}$ M. P o p r z ę c k a, Galeria. Sztuka patrzenia, Wydawnictwo Stentor, Warszawa 2003, s. 9. 
Łacinnicy, gdy pytają: „po co?”, „dlaczego?”, „,w jakim celu i z jakim skutkiem?”, powiadają: „cui bono?”. Jest to pytanie, nie tylko o dobro czy korzyść jakiejś osoby, ale właściwie o sens. Owego sensu poszukujemy zarówno w ocenie programów, koncepcji czy decyzji. Dotyczy to szczególnie kwestii sądowych oraz moralnych, ale także teologicznych. Jakby intuicyjnie kojarzy się tu znana zachęta nauczycieli, by dany tekst nie tylko czytać głośno i wyraźnie, ale przede wszystkim - ze zrozumieniem. Pytamy np. o wykładnię biblijną jakiejś księgi czy fragmentu Pisma Świętego. Analizujemy nie tylko warstwę językową, filologiczną, lecz próbujemy dociec, jaka jest egzegetyczna wykładnia danego tekstu, ale odczytujemy go „również przez pryzmat wiary, czyli na płaszczyźnie egzystencjalnej”'13. Pytamy o interpretację przypowieści, metafor czy analogii. Próbujemy przybliżyć je współczesnemu odbiorcy. Sensowne jest więc pytanie o coś więcej, niż tylko katechizmowe zrozumienie swojej wiary ${ }^{14}$. W konsekwencji poszukujemy sensu teologicznego i autentycznej prawdy. Czyż poszukiwaniem tego nie jest wiele kwestii, które stawia w 20. roku swego pontyfikatu Jan Paweł II w swej encyklice Fides et ratio ${ }^{15}$

Gdy sprawujemy świętą liturgię, to dbamy o to, co się określa jako „ars celebrandi”. Poszczególne słowa, gesty czy przestrzenie nie są celem samym w sobie. Istotna jest ich głębia i autentyzm. Zarówno celebransi, asysta, jak i uczestniczący wierni tworzą wspólnotę ludu

13 G. R a v a s i, Święte Księgi. Jak czytać i rozumieć Pismo Święte, Wydawnictwo Esprit, Kraków 2015, s. 6, por. s. 97-103.

14 J. P e n r i c e, Młodość i chrześcijaństwo czyli zrozumieć swoją wiare, Wydawnictwo WAM, Kraków 1998.

15 J a n P a w e 1 II, Fides et ratio, Encyklika podpisana 14 września 1998. Oto wybrane dwa fragmenty: „Istnieje jedyna w swoim rodzaju więź wzajemności. W Bogu znajduje się początek wszystkich rzeczy, w Nim mieszka pełnia tajemnicy i to stanowi Jego chwałę; człowiek ma zadanie badać rozumem prawdę i na tym polega jego godność” (nr 17); „Złudne jest mniemanie, że wiara może silniej oddziaływać na słaby rozum; przeciwnie, jest wówczas narażona na poważne niebezpieczeństwo, może bowiem zostać sprowadzona do poziomu mitu lub przesądu. Analogicznie, gdy rozum nie ma do czynienia z dojrzałą wiarą, brakuje mu bodźca, który kazałby skupić uwagę na specyfice i głębi bytu” (nr 48). 
Bożego. Wszyscy współtworzą Mistyczne Ciało Chrystusa, właśnie szczególnie podczas sprawowania liturgii mszalnej. Nie jest to jednak jedynie zgromadzenie wiernych, ale uczestniczenie w Ofierze Chrystusa. Tu dotykamy istoty i sensu każdej Mszy świętej. Jaką głębię teologiczną, biblijną i symboliczną odkrywamy, gdy np. uczestniczymy w obrzędzie poświęcenia ołtarza i kościoła.

Słusznie zauważa Hans Urs von Balthasar, że wolność połączona z pełną ekspresją - nie tylko w dziedzinie sztuki - oznacza działanie, „w którym zarówno zgodnie z konwencją, jak inwencją podmiot duchowy może komunikować swoją wewnętrzność"16. Dobitnie mówi o tym Jan Paweł II w Liście do artystów: „Artysta, im lepiej uświadamia sobie swój «dar», tym bardziej skłonny jest patrzeć na samego siebie i na całe stworzenie oczyma zdolnymi do kontemplacji i do wdzięczności, wznosząc do Boga hymn uwielbienia. Tylko w ten sposób może do końca zrozumieć samego siebie, swoje powołanie i misję. [...] Tworząc dzieło, artysta wyraża bowiem samego siebie do tego stopnia, że jego twórczość stanowi szczególne odzwierciedlenie jego istoty - tego kim jest i jaki jest. Znajdujemy na to niezliczone dowody w dziejach ludzkości. Artysta bowiem, kiedy tworzy, nie tylko powołuje do życia dzieło, ale poprzez to dzieło jakoś także objawia swoją osobowość. Odnajduje w sztuce nowy wymiar i niezwykły środek wyrażania swojego rozwoju duchowego. Poprzez swoje dzieła artysta rozmawia i porozumiewa się z innymi. Tak więc historia sztuki nie jest tylko historią dzieł, ale również ludzi. Dzieła sztuki mówią o twórcach, pozwalają poznać ich wnętrze i ukazują szczególny wkład każdego z nich w dzieje kultury" (nr 1,2) ${ }^{17}$.

Warto spojrzeć na całe życie chrześcijańskie, jako na ustawiczne odkrywanie $\mathrm{i}$ to twórcze odkrywanie kształtu i barwy wiary. To poeta, Roman Brandstaetter, tak pięknie ukazał przecież nie tylko ową modlitewną więź z Bogiem. Jakże bardzo przypomina to język sztuki oraz twórczy wysiłek naszego ratio:

16 H.U. v on B a 1 t h a s a r, Epilog, Wydawnictwo WAM, Kraków 2010, s. 54.

${ }_{17} \mathrm{~J}$ a n P a w e 1 II, List do artystów, Księgarnia Świętego Wojciecha, Poznań 2007, s. 7-8. 
O, daj nam Panie, natchnienie do wiary, Albowiem wiara jest trudną twórczością, Która wymaga czujności sumienia, Ognia, pokory i woli, bez której Nie ma modlitwy ani nie ma skruchy I świadomości popełnionych grzechów.

Bo wiara w Ciebie winna być tworzywem, W którym się człowiek cały wypowiada Jak malarz w barwie, jak poeta w słowie, Jak kompozytor w układaniu dźwięków. Każdy z nas musi tę wiarę kształtować Według wymogów swojej twórczej woli, Według potrzeby swej osobowości.

I ten wysiłek nawet nie wystarczy, Bo chcąc naprawdę wierzyć w Ciebie, Boże, Musimy zostać artystami wiary I nieustannie tę wiarę zdobywać, I wciąż od nowa zdobywać jej głębię, Jak zdobywamy nowe słowo w wierszu, Jak zdobywamy nowy dźwięk w muzyce I nowe barwy na płótnie obrazu.

Każda rutyna i każda maniera

Są śmiercią wiary i śmiercią sumienia.

O, daj nam, Panie, natchnienie do wiary!

\section{OPCJA INTEGRALNA}

Zacznijmy od tego, co katechizm określa jako dary Ducha Świętego. Dotykamy nie tylko bliskich skojarzeń, ale wzajemnego ich przenikania i współtowarzyszenia w różnych sytuacjach. Czyż 
również wokół poruszanych tu teoretycznych i praktycznych problemów związanych ze sztuką, niemal intuicyjnie poszukujemy właśnie: mądrości, rozumu, rady, umiejętności, roztropności i także zdrowej pobożności czy bojaźni Bożej? Jaką głębię wskazuje autor, choćby w tym krótkim fragmencie: „Istotna kwestia dotyczy nie tyle inicjacji 'w' Mądrość, ile raczej inicjacji Mądrości w nas - dzięki Niej, która tego dokonuje. Wszystko dzieje się przy Jej udziale, trzeba tylko to zauważyć: otworzyć się na Nią, dać się prowadzić"18. To teologiczne odniesienie do praźródła relacji sapiencjalnych, każe wspomnianemu autorowi pisać o tym darze wielką literą.

W różnym stopniu sztuka często odnosi się do otaczającego świata - do saeculum. Mocno zakorzeniona jest więź, a nawet przenikanie sztuki z naturą, czego skrajnym przejawem jest język sztuki, który sprowadza się do imitacji natury, szczególnie w stylu nazwanym naturalizmem. Jest jednak także zjawisko odwrotne: upodabnianie natury do sztuki, czego przykładem jest artystyczne kształtowanie ogrodów czy tworzenie pejzażu oraz martwej natury ${ }^{19}$. Obydwie kwestie są przejawem nie tylko twórczości artystycznej, ale zarazem - procesem intelektualnym.

Kolejnym zjawiskiem, które dotyczy pewnych twórców jest tendencja interdyscyplinaryzmu ${ }^{20}$, czyli świadome i celowe działanie na różnych polach artystycznej ekspresji. Malarze bardzo często nie tylko korzystają z poezji, ale sami piszą wiersze a nawet poematy. Inni łączyli swoją wrażliwość muzyczną, zainteresowanie baletem czy tańcem przy twórczości rzeźbiarskiej czy malarskiej. Teoretyczne przemyślenia i pomysły wynikające z kierunku zwanego unizmem, posłużyły nie architektom, ale malarzom, Władysławowi

18 J. B o le w s k i, Inicjacja Mądrości. Dla życia, duchowości, teologii, Wydawnictwo Święty Wojciech, Poznań 2012, s. 7.

19 Z. W a ź b i ń s k i, Ut Ars Natura, Ut Natura Ars, Wydawnictwo UMK, Toruń 2000, s. 9, 168-179. 227-247.

${ }^{20}$ M. P or ę b s k i, Sztuka a informacja, Wydawnictwo Literackie, Kraków, Wrocław 1986, s. 174-176. 
Strzemińskiemu i jego żonie Katarzynie Kobro, do tworzenia bardzo oryginalnych koncepcji przestrzennych.

Zarówno artysta, jak i widz zwiedzający kolekcję w muzeum, poddaje się nie tylko emocjom i wrażeniom, ale dokonuje także oceny, rozwagi, osądu. Nawet to, co jest działaniem par excellence artystycznym, poddane zostaje zarazem pewnemu procesowi intelektualnemu. Dotyczy to zarówno dzieł utrzymanych w tradycyjnym kanonie stylistycznym czy formalnym, jak i oderwanych od historycznych nawyków i skojarzeń. Obydwie opcje budzą zainteresowanie, skłaniają do refleksji. Trafnie powiada się, że arcydzieła dawnej architektury i sztuki, to - mówiąc słowami św. Tomasza z Akwinu - zarówno sacra doctrina, jak i rodzaj katechezy - Biblia pauperum, czy też bezdźwięczne kazania wykute w kamieniu, czy prześwitujące w witrażach. Podkreślmy, że znajduje to odzwierciedlenie w teocentrycznym myśleniu i działaniu: „Bóg i jego sprawy, rozważane $\mathrm{w}$ świetle objawienia i poparte rozumem, stanowią właściwy przedmiot $\mathrm{w}$ teologii, rozumianej jako nauka (scientia) o sprawach wiary"21. Wchodząc do bazyliki romańskiej czy katedry gotyckiej, musimy mieć choćby podstawową wiedzę czy informację o specyfice danej epoki, kultury, stylu. Warto podkreślić złożoność i wielowarstwowość stylu jako zjawiska i procesu, który precyzuje oraz indywidualizuje zarówno epokę, środowisko, jak i twórcę. Dotyczy to nie tylko rozmaitych dokumentów i innych tekstów, lecz także twórczości plastycznej22. Jakże ważne jest zrozumienie świata

${ }^{21}$ P. B r o w n, Narodziny zachodniego chrześcijaństwa, Wydawnictwo Krąg, Warszawa 2000, s. 55; Krzysztof Bracha, Teolog - intelektualista i duszpasterz w społeczeństwie średniowiecznym, w: Wojciech Fałkowski (red.), Kolory i struktury Średniowiecza, Wydawnictwo DIG, Warszawa 2004, s. 138.

${ }^{22}$ M. P or ę b s k i, Sztuka a informacja..., s. 186-187: „W każdej formule stylowej rozróżnić możemy mianowicie jej warstwę technologiczną, która decyduje o materialnej fa k t u r z e dzieła, warstwę morfologiczną, która określa jego a r t y k u l a c j ę, przekształcając spójny i zwarty o b r a z technologiczny w rozpadający się na ustalone jednostki konstytutywne t e k s t, warstwę ikonograficzną, która organizuje takie mniejsze i większe jednostki w określone motywy, tematy i cykle tematyczne i wreszcie warstwę poetycką, która ustosunkowuje ów tekst do 
i człowieka również w kontekście myśli filozoficznej, teologicznej, czy literatury ${ }^{23}$ tamtego czasu, a także korelacji między wizją artystyczną a wyobraźnią i talentem twórcy, jak i wpływającymi na niego ówczesnymi tendencjami intelektualnymi. Podkreśla się wręcz fascynujące połączenie platońskiego intelektualizmu z duchem kontemplacji w ikonach bizantyjskich i liturgii Wschodu ${ }^{24}$.

Znamienne były i są reakcje na nie tylko nietypowe, ale wręcz jakby zabronione metody i techniki. To szczególnie wyraziście dotyczy swego rodzaju poszukiwania, świadomego odchodzenia od przyjętych kodów. Wyraźnie widać to na przykładzie impresjonistów. Kolory wymyślano, kojarzono kompozycyjnie, ale nie były one odtwarzaniem rzeczywistości czy zjawisk natury. Niebieskie drzewa czy zielone słońce było przejawem wydźwięku alegorycznego czy symbolicznego.

Zadaniem historyka sztuki, a tym bardziej teologa sztuki jest badanie, opisywanie, analiza oraz wielowątkowa interpretacja danego dzieła. Jakże cenne jest dostrzeżenie specyficznych estetycznych środków wyrazu. Jednakże błędem byłby osąd koncentrujący się wyłącznie na optycznych jakościach dzieła, jego formie i strukturze. Właśnie owo ratio podkreśla jeden z autorów: „Interpretacja humanistyczna obejmuje również interpretację dzieła sztuki, ponieważ jest ono, jak zakładam, szczególnym przypadkiem wytworu czynności racjonalnej. Interpretacji humanistycznej poddawane są [...] nie tylko

jego jednostkowego i kulturowego zaplecza - do warunkującego go p o d t e k s t u twórczych decyzji i motywacji oraz do właściwego mu k o n t e k s t u reprezentowanych w nim postaw, pojęć i wyobrażeń".

${ }^{23}$ U. E c o, Historia piękna, Dom Wydawniczy Rebis, Poznań 2005, s. 12: „Często w obliczu dokumentu sztuki albo dawnego rzemiosła pomocne nam będą literacie i filozoficzne teksty epoki”.

${ }_{24}$ M.A. K r ą p i e c, Chrześcijaństwo - wspólne dobro Europy, „Znak” $191 \mathrm{nr} 9$ (327), s. 1164/5: „Intelektualna kontemplacja idei znalazła swój religijny odpowiednik w ikonach bizantyjskich, które czczono jako okno otwarte na świat nadprzyrodzony. Obrzędowość Wschodu znalazła swój pełny wyraz w bogatej liturgii, która pozwalała spokojnie kontemplować odbijające się w niej piękno, prawdę i dobro i skłaniała do miłości, która porywa wszystkie siły twórcze i ogniskuje je w sakramentalnie obecnym wcielonym Logosie". 
odpowiednie cechy dzieła sztuki jako całości, lecz również wybrane cechy jego składników. [...] Centralnym zagadnieniem interpretacyjnym jest zawsze kwestia: co i jak - komunikuje dzieło sztuki. Wszelkie zabiegi interpretacyjne dokonywane nad dziełem sztuki, nawet jeśli nie zdążają do odpowiedzi na pytanie tego rodzaju, stanowią środek pośrednio służący do jego rozwiązywania"25.

Coraz częściej dąży się do stworzenia metody integralnych badań historycznych nad sztuką. Jednocześnie zwraca się uwagę na konieczność współpracy wielu nauk humanistycznych, a nawet ścisłych. Chodzi o uwzględnienie nie tylko różnych dyscyplin historycznych, ale podjęcie kompleksowych badań morfologicznych, jak również „badań strukturalnych, łączących zresztą analizy formalne z interpretacją treści ideowych" 26 . Owe różne podejścia do analizy i oceny dzieł sztuki, są przejawem szerszego, wielowątkowego potraktowania w tym kontekście wspomnianego ratio.

\section{SACRUM KOŚCIELNE}

Począwszy od całej zewnętrzności, poprzez konstrukcję, strukturę, elementy techniki i technologii, każdy obiekt sakralny jest dziełem, które scala w jedno zarówno treść, jak i formę. Owa treścioforma powinna za każdym razem być indywidualnym, oby oryginalnym, dziełem architekturoplastyki o znamionach sakralnych. Dodałbym, że każdy, także współczesny kościół powinien oczywiście integralnie wpisać się w otoczenie, w krajobraz, ale także poprzez zawarty integralny przekaz, powinien wpisać się w zdrowy nurt prądów czy kierunków artystycznych epoki. Powiedzmy więcej, czy stara się być pionierem i liderem, a tym samym nawiązać do czasów, gdy właśnie mecenat Kościoła i jego działania fundacyjne

25 W. Ł a w n i c z a k, Teoretyczne podstawy interpretacji dziet sztuki plastycznej, Wydawnictwo Naukowe UAM, Poznań 1975, s. 3n.

26 J. B i ało s t o c k i, Sztuka i myśl humanistyczna. Studia z dziejów sztuki i myśli o sztuce, Państwowy Instytut Wydawniczy, Warszawa 1966, s. 156. 
spełniały rolę wiodącą, a nawet nadawały kierunek integralnemu myśleniu i działaniu.

Nieraz podkreślam, że do osiągnięcia tego, niezbędna jest symbioza trzech cech: fides, ratio i ars, w odniesieniu do konserwowanego czy odrestaurowanego zabytku kościelnego ${ }^{27}$, choć nie tylko. Owa triada dotyczy również zupełnie nowego kościoła. Pragnę zarazem zauważyć, że zarówno w odniesieniu do nova, jak i vetera sacrum kościelnego, szczególne znaczenie ma właśnie ten centralny element. To przecież ratio wiąże i organizuje dwa pozostałe. Zarówno bowiem opcja wiary, teologii, liturgii, ikonografii, symboliki..., jak i estetyka całości i jej charakter artystyczny, mają swe oparcie w opcji intelektualnej. Chcąc stworzyć dzieło, które jest przejawem autentycznej wiary, zgodności z nauką Kościoła, z Credo, z dogmatami i przykazaniami, musimy sięgnąć do tekstów, do doktryny i rozumowo to przeanalizować. Oprócz Biblii, ważne są także dokumenty soborów czy synodów, Katechizm Kościoła Katolickiego, a także przepisy prawa kanonicznego i liturgicznego ${ }^{28}$.

Wspomnijmy tu choćby jeden wątek - hagiografię. Oto inwestor otrzymuje dekret miejscowego biskupa, by postawić nowy kościół, któremu patronować będzie konkretny święty. Oczywiście, że niezbędne jest przestudiowanie życiorysu tego patrona, ale także wraz z twórcami zastanowienie się nad tym, jak tę postać przybliżyć wiernym w owym nowym kościele. Jest olbrzymia literatura hagiograficzna, która może to ułatwić. Wspomnijmy tylko o kilku. Ukazała się np. tłumaczona z włoskiego pozycja, która może stać się cenną lekturą przy wyborze patrona ${ }^{29}$. Autor przedstawia świętych jako pośredników w szczególnych momentach życia: w chorobach i nieszczęściach, w małżeństwie i macierzyństwie, w uprawianiu

${ }^{27}$ H. N a d row s k i, Relacje ,fides”, ,ratio” $i$,ars” w zabytkowym kościele. „Zeszyty Naukowe Politechniki Białostockiej, Budownictwo”, 2006 nr 30, s. 289-306.

${ }_{28}$ Z. W i t, Podstawy liturgiczno-prawne miejsca celebracji odnowionej liturgii, w: W. Ś w i e r z a w s k i (red.), Sztuka w liturgii, Zawichost, Kraków, Sandomierz 2013, s. 346-349

${ }^{29}$ R. C a m mill e r i, Wielka księga Świętych Patronów, Wydawnictwo Jedność, Kielce 2001, s. 536. 
zawodów, sztuki oraz wyborze powołania. Innym cennym poszukiwaniem jest wydobycie i ukazanie charakterystycznych atrybutów poszczególnych świętych. Ten aspekt wydobywa niedawno opublikowana olbrzymia praca ${ }^{30}$, która wylicza i opisuje aż 20 motywów tematycznych; od trynitarnych, chrystologicznych, mariologicznych, angelologicznych, antropologicznych, przyrodniczych, architektonicznych, aż po muzyczne i heraldyczne. Kolejna publikacja ukazała się w Wydawnictwie Jedność, we współpracy ze znanym wydawnictwem w Mediolanie. To edytorsko świetnie i estetycznie opracowane wydanie albumowe. Książka jest historycznym atlasem świętych, wraz z ich słownikiem, ikonografią oraz indeksem przypisanych im atrybutów $^{31}$. Aby więc przystąpić do dzieła, potrzebna jest to pewna wiedza i nawiązanie do przyjętych typów ikonicznych. To minimum ma zarazem uchronić przed ujęciami bluźnierczymi czy wręcz heretyckimi. Ma zarazem dopomóc w utrzymani ładu przestrzennego we wnętrzu, jak i hierarchii przedmiotów oraz wizerunków świętych. W Konstytucji o liturgii i Ogólnym Wprowadzeniu do Mszału Rzymskiego znajdujemy też pouczenie, by w danej przestrzeni liturgicznej nie były powtarzane przedstawienia tego samego świętego. Takie poznawcze podejście dotyczy każdego aspektu związanego z wydobyciem czy zaakcentowaniem wspomnianych fides oraz ars w powstającym nowym obiekcie kultu.

Jakże ważne jest rozstrzygnięcie, czy w danym kościele powinny być witraże, a jeśli tak, to jakie. Projektujący je powinien rozeznać lokalizację, ukierunkowanie światła i rangę dominanty kolorystycznej. Powinien to uczynić zanim zacznie opracowywać szkic czy konkretny projekt ${ }^{32}$.

30 J. M a r e c k i, L. R o t t e r, Jak czytać wizerunki świętych. Leksykon atrybutów i symboli hagiograficznych, Universitas, Kraków 2009, s. 14-21.

${ }^{31}$ F. i G. L a n z i, Jak rozpoznać świętych i patronów w sztuce i wyobrażeniach ludowych, Wydawnictwo Jedność, Kielce 2004, ss. 239.

32 W. O s tr z ołe k, Moje witrażowe Stegny, w: T. M i e r z w i ń s k i (red.), Witraże stegieńskie Wiktora Ostrzołka. Miłosierdzie Boże w historii zbawienia. Wydawnictwo Księży Marianów, Warszawa 2003, s. 13: „Ja wchodzę do wnętrza i staram się optymalnie poznać i zrozumieć, a nade wszystko odczytać działanie 
Zasadniczo nie preferuję szczegółowego wskazywania, jak należy wykonać prace związane z konkretnym obiektem kultu, bo za każdym razem powinien on być potraktowany indywidualnie. Jednakże dla osób, które „wchodzą” w tę specyficzną dziedzinę twórczości, niezbędna jest wielowątkowa lektura, która powinna ułatwić podejmowanie właściwych decyzji. Poniżej wspominam dwie publikacje, które choć częściowo są nieaktualne, to cenne są dzięki kompleksowemu potraktowaniu problemu. Pierwsza, skupia się na praktycznych poradach i zaleceniach, które mają , charakter doradczy w zakresie budowy kościołów i ich należytej konserwacji”, jak czytamy we Wstępie ${ }^{33}$. Książka zawiera 15 rozdziałów, których autorami są wyłącznie reprezentujący środowisko stolicy. Druga pozycja jest monumentalnym dziełem jednego autora ${ }^{34}$. Jest jeszcze wcześniejszą publikacją i zawiera niektóre wątki obecnie nieaktualne, gdyż pisana była przed Vaticanum II. Mimo więc częściowej dezaktualizacji, ma charakter interdyscyplinarny i poniekąd encyklopedyczny.

Równie wielowątkowa jest pozycja już posoborowa ${ }^{35}$, zawierająca 20 artykułów, głosy w dyskusji oraz nadzwyczaj ważną końcową część Kościół a sztuka współczesna. Bibliografia polska za lata 1945-1986, która obejmuje noty 1641 publikacji. Na uwagę zasługuje też wznowiona (wydanie I w 1996 roku) praca zbiorowa z niezbędnym minimum ratio z zakresu relacji między sztuką a liturgią. W nowej, uzupełnionej edycji znajdują się teksty 15 autorów wraz z merytorycznymi notami o nich ${ }^{36}$.

światła, które jest zróżnicowane [...]. To trzeba wyczuć i zadany czy wymarzony temat «włożyć» w konkretne okno, jego konstrukcję, tak, by maksymalnie wykorzystać światło i stworzyć jego magię".

${ }_{33}$ Budowa i konserwacja kościołów. Poradnik-Vademecum. Praca zbiorowa, Rada Prymasowska Budowy Kościołów, Warszawa 1981, ss. 335.

${ }^{34} \mathrm{Ch}$. Z i e 1 i ń s k i, Sztuka sakralna. Co należy wiedzieć o budowie, urządzeniu, wyposażeniu, ozdobie i konserwacji Doтu Bożego, Księgarnia św. Wojciecha, Poznań 1960, ss. XXXVI, 1004.

${ }^{35}$ N. C i e śl i ń s k a (red.), Sacrum i sztuka, Wydawnictwo Znak, Kraków 1989.

${ }^{36}$ W. Ś w i e r z a w s k i (red.), Sztuka w liturgii, Zawichost, Kraków, Sandomierz 2013, ss. 511. 
Pewną podstawową wiedzę o istocie zabytków kościelnych oraz postawach i zachowaniach względem nich, można zaczerpnąć z popularnej, ale cennej przedmiotowo niewielkiej „książki dla księży”, jak głosi podtytuł. Jednakże z pożytkiem skorzystać z niej mogą także inne osoby duchowne, zakonne, jak również świeccy ${ }^{37}$. Oczywiście nie sposób w tym krótkim tekście przeanalizować osiągnięcia i specyfikę kilku naszych polskich szkół konserwatorskich, ani wskazywać na technikę i technologię różnych materiałów, co zresztą jest przedmiotem wieloletnich studiów specjalistycznych i praktyk. Chcę jednak zwrócić uwagę na książkę ks. Janusza St. Pasierba, która po raz pierwszy ukazała się w roku 1968. Drugie jej wydanie jest „poprawione i uzupełnione”, jak czytamy na stronie tytułowej dotyczy postawy wobec zabytków kościelnych, które są funkcjonującymi obiektami kultu, czy też mają charakter muzealny. Do tekstów autora dodano m.in. bardzo przydatny aneks, który zawiera Wskazówki bibliograficzne do poszczególnych rozdziałów oraz „wypisy z najważniejszych dokumentów państwowych i kościelnych dotyczących ochrony i konserwacji zabytków w Polsce"38.

Nie sposób pominąć jakże ważną sprawę, która dotyczy koncepcji i realizacji konkretnego obiektu sakralnego. Chodzi najpierw o dobór właściwych twórców tzn. kompetentnych i związanych z doktryną chrześcijańską. $Z$ drugiej strony, należy uszanować i docenić wieloraki, także intelektualny, wysiłek związany z prawami autorskimi przy kształtowaniu wyrazistego i konsekwentnego programu całości, wraz z podkreśleniem hierarchii poszczególnych elementów. Dobry projektant zadba o integralność i spójność całej kompozycji, czego tak zdecydowanie bronił w swych tekstach Roman Ingarden. Chodzi o przemyślaną aranżację ogółu i szczegółu, tak iż owa końcowa koncepcja staje się dziełem zamkniętym i dopełnionym. Właściwie

37 B.J. R o u b a, Pielęgnacja świątyni. Książka dla księży, Toruńskie Wydawnictwo Diecezjalne, Toruń 2000, ss. 128.

38 J.S. P a s i e rb, Ochrona zabytków sztuki kościelnej, przygotował: Jerzy Żmudziński, Biblioteka Towarzystwa Opieki nad Zabytkami, Warszawa 1995, ss. 242, ilustr. 81 . 
nie powinno być cokolwiek ujmowane, ani też dodawane. W fazie dyskusji artysta powinien wykazać się odpowiednią wiedzą, ale zarazem być człowiekiem dialogu, który wsłuchuje się w sensowne uwagi inwestora-teologa oraz miejscowych wiernych. Nieraz jednak budzi się w nim sprzeciw, a przynajmniej dylemat, czy kontynuować współpracę, skoro wspomniane dwa środowiska jakby dla zasady nie tyle współpracują z nim, ile raczej kontestują wszelkie jego pomysły. Zdarza się, że po długich dysputach i przyjęciu jego autorskiego przesłania, nagle np. komisja diecezjalna przekreśla cały jego wysiłek i nie tyle wnosi korygujące uwagi, ile raczej staje się adiustatorem czy nawet cenzorem. Ważna, a może nawet najważniejsza jest owa faza obmyślania programu całości. I słusznie. Jej efektem powinien być konkretny projekt realizacyjny. Skoro w końcu zostaje przyjęty i zatwierdzony, to należy wiernie go przestrzegać. Z tym wiąże się też zachowanie prawa autorskiego. Projektanci i artyści bywają pomijani w dokumentacji przy akcie erekcyjnym czy konsekracji nowego kościoła. Choć w wygłaszanej czy napisanej laudacji wymienia się cały kontekst struktur kościelnych: od papieża, poprzez członków komisji kurialnej, miejscowego proboszcza a nawet wikarych, a zarazem zupełnie pomija się tych, którzy koordynowali oraz dopełniali teologicznie i artystycznie - właśnie owo ratio danego kościoła.

\section{PRZEKAZ WOKÓŁKOŚCIELNY}

Najpierw uświadamiamy sobie i innym, że identycznie brzmiące dwa słowa „Kościół” i „,kościół”, nie utożsamiają się. Pierwsze dotyczy wspólnoty ochrzczonych i skupionych wokół Jezusa Chrystusa; drugie dotyczy tych samych relacji i przynależności, ale w odniesieniu do budowli, w której gromadzą się wierni. To rozróżnienie a zarazem pewne wspólne elementy należy przekazywać w nauczaniu. Zarazem trzeba mocno podkreślać opcję, która łączy obydwa. Chodzi o ujęcie personalistyczne. Otóż wierni to żywe kamienie ustawicznie gromadzącego się żywego Kościoła. Przestrzenią ku temu są mury obiektu kultu, który zarazem ciągle przygotowuje do rzeczywistości eschatycznej, do Kościoła uwielbionego, czyli do nieba. 
Ważne jest wprowadzanie poprzez dom rodzinny czy katechezę w treść i formę przestrzeni sakralnej. Jakże cenne jest osobiste przyprowadzanie dziecka do budynku kościelnego i to zarówno w ciszy, bez tłumów wiernych, jak i podczas sprawowanej liturgii. Wielką sztuką jest uwrażliwienie dziecka, by uszanowało godność tej szczególnej przestrzeni w obydwu relacjach.

Jest taka książka „Chodź, pokażę Ci kościót”, która może ułatwić objaśnianie zarówno miejsca, wyposażenia, sprzętu, szat liturgicznych. Publikacja ta pomyślana jest jako pomoc, by przez dorosłych służyć dzieciom, „,kiedy pytają, co odróżnia kościoły od innych budowli, kiedy chcą się dowiedzieć, co się w nich dzieje i jak należy się zachowywać, wchodząc do środka"39. Także bowiem dzieciom należy w przystępny sposób przekazać owo ratio obiektu kultu, akcentując istotne różnice $\mathrm{w}$ porównaniu $\mathrm{z}$ innymi miejscami, przedmiotami życia codziennego, które jednak nie są związane z liturgią, modlitwą czy adoracją.

Warto również sięgnąc do nieco nietypowo zredagowanej, ale bogatej treściowo książki, w której autor stawia pytanie i zarazem na nie odpowiada: ,jak czytać kościół?” Pozycja interesująca, choć pisana dla czytelnika angielskojęzycznego, stąd pewne szczegóły mogą zaskakiwać polskiego czytelnika. Bezsprzecznie ta publikacja może służyć jako cenna lektura o znamionach erudycyjnych. Oto wprowadzająca myśl autora: „Celem tej książki jest pomóc osobom odwiedzającym kościoły (czy to wiernym uczestniczącym regularnie w nabożeństwach, czy to turystom, niezależnie od ich światopoglądu) lepiej zrozumieć bogactwo i głębię tego, co ich otacza"40. Tak, właśnie „zrozumieć” wspominane oba aspekty obiektu kościelnego. Czyli autor w jakiś sposób podejmuje wspomniane w tytule ratio.

39 M.L. G o e c k e-S e i s c h a b, F. H a r z, Chodź, pokażę Ci kościót. Poradnik dla rodziców, wychowawców, nauczycieli, Instytut Wydawniczy Pax, Warszawa 2003, s. 7.

${ }^{40}$ R. T a y 1 o r, Przewodnik po symbolice kościoła, Klub dla Ciebie, Warszawa 2006, s. 11 . 
Jakże ważną rolę informacyjną, a zarazem katechetyczną pełni tablica umieszczona na zewnątrz lub w kruchcie, która przedstawia dzieje danego kościoła oraz opisuje cenne dzieła czy przedmioty. To może mieć też charakter małego przewodnika po kościele. Dotyczy to głównie kościołów zabytkowych, ale także współczesnych. Wskazane jest też umieszczanie choćby skrótowej informacji w którymś z języków obcych.

Wreszcie należy docenić rolę przewodnika, który oczywiście powinien uprzednio być należycie przygotowany do pełnienia jakże istotnej merytorycznie i dydaktycznie funkcji. A jest to przecież zarazem forma ewangelizacji. Niesamowicie ważny jest dobór właściwych słów i argumentów oraz umiejętny sposób ich przekazu. Pewnym ideałem jest połączenie elementów racjonalnych z obrazowym, także emocjonalnym i zaangażowanym sposobem emisji1 ${ }^{41}$. Ten, który wprowadza słuchaczy w specyfikę czasu i miejsca, w to, co określane jest jako genius loci, powinien poświęcić więcej uwagi konkretnym osobom czy to wydarzeniom owego „tu” i ,teraz”. Należy przybliżyć odbiorcom historyczny i współczesny rys konkretnej przestrzeni kościelnej. Właśnie wszystkim, dla których język jest nie tylko istotnym medium realizacji ludzkiej egzystencji, lecz środkiem komunikacji i ekspresji artystycznej, należy uprzytamniać, jak wielki to dar i z jaką wiąże się odpowiedzialnością. Także ci, którzy są przewodnikami w obiektach kultu powinni w życie wprowadzać jakże trafną myśl Josepha Ratzingera o międzypokoleniowej roli języka: „Nabiera on sensu przez to właśnie i w tym, że łączy mnie z ludźmi, którzy mnie otaczają teraz i którzy żyli przede mną. Język jest wyrazem ciągłości ludzkiego ducha w historycznym rozwoju jego istoty ${ }^{\prime 2}$.

${ }^{41}$ M. F il i p i a k, Homo communicans. Wprowadzenie do teorii masowego komunikowania, Wydawnictwo Uniwersytetu Marii Curie-Skłodowskiej, Lublin 2003, s. 119: „Najbardziej skuteczna byłaby właściwa proporcja argumentacji racjonalnej popartej ekspresją emocjonalną. [...] To, co emocjonalne nie musi być nieracjonalne, nielogiczne".

42 J. R a t z i n g e r, Opera omnia, t. XI Teologia liturgii, Wydawnictwo KUL, Lublin 2012, s. 196. 
Rolą przewodnika powinno być też dyskretne, ale zarazem konsekwentne przypominanie przychodzącym tam, by przestrzegali zasady odpowiedniego, stosownego ubioru oraz godnego zachowania tamże. Zapewne budujący wpływ na słuchaczy będzie wywierała jego osobista postawa, czy np. gest przyklękania wobec Najświętszego Sakramentu w tabernakulum lub w monstrancji. Niewątpliwie wszelkie przejawy jego wiary, wzmocnią percepcję jego przekazu merytorycznego.

\section{KU NIESKOŃCZONOŚCI}

Znamienne, że zwraca się uwagę na myślenie i widzenie tego, co zewnętrzne, ale też tego, co wewnętrzne. Jest jednak także trzeci zakres myślenia, który kieruje ku nieskończoności, ku przekraczaniu wizualnych przedmiotów. Chodzi więc o rzeczywistość, która przerasta wszelkie wyobrażenie i naszą wyobraźnię. Owa refleksyjna aktywność zmierza „do zrozumienia rzeczy, które są zawsze nieobecne, o których nie mamy pamięci, bowiem nie były one nigdy obecne w doświadczeniu zmysłowym"43. Dotykamy tu poszukiwania i odkrywania najgłębszego sensu - metafizycznego. Ta sfera wymaga zatrzymania się i głębszej refleksji. Nie jedynie w kontekście śmierci, pogrzebu czy nawiedzenia cmentarza, stawiamy podstawowe pytania egzystencjalne, a raczej usensowiające poprzez pryzmat eschatyczny. Wobec owych wielorakich relacji między Bogiem i człowiekiem, stajemy z wieloma pytaniami i to nie tylko z zakresu teologii i sztuki ${ }^{44}$.

${ }^{43}$ H. A re nd t, Roztargnienie filozofa, ,Znak” 1981 nr 9 (327), s. 1268.

44 H. N a d row s k i, Język wiary a wyraz sztuki, w: P. B or tk i e w ic z, $\mathrm{S}$. M i k oła j c z a k, M. R y b k a (red.), Język religijny dawniej i dziś (w kontekście teologicznym i kulturowym), t. 5. Materiaty z konferencji, Gniezno 22-24 września 2008, Wydawnictwo Poznańskie Studia Polonistyczne, Poznań 2008, s. 141: „Jak Bóg i człowiek jest odbierany poprzez pryzmat sztuki, ale i w nią ,ubierany”? Czy ten kontekst zakłóca, czy raczej pogłębia dany tekst? Czy optyka sztuki obiektywizuje rzeczywistość? Czyż prawda lub prawdziwość przekazane środkami języka sztuk pięknych, to właściwie ciągle subiektywne a zarazem bardzo kreatywne podejście do tematu, do zdarzenia, do stanów psychicznych poszczególnych osób i tłumów”. 
Zauważmy, że nie tylko w literaturze świadomie akceptujemy przesłanie dzieła, ale próbujemy „również odsłonić jego sens”. To konsekwentnie właśnie „odbiorca jest instancją ujawniającą, współtworzącą teologiczny sens wewnętrzny i zewnętrzny" - jako człowiek przeżywający swoją wiarę, swój stosunek do Boga ${ }^{45}$. Jakże często percepcja dzieła, a raczej jego interpretacja, po wielu latach a nawet po wiekach, odbiega od intencji twórcy. Dzieło żyje jak gdyby własnym życiem. Przerasta nie tylko czasowo artystę, ale także jakby zmienia swoją „tożsamość" - właśnie swoje ratio. Znany malarz i zarazem duchowny ks. Jerzy Wolf kończy jeden ze swych rozdziałów stwierdzeniem, że dzieła sztuki, poprzez swoją kompozycję, kolorystykę i rozmaite detale mogą zachwycać a nawet fascynować. Dodaje zarazem, że istnieją one „ku radości tych wszystkich, którzy sztukę kochają - sztukę nade wszystko myślenia, która z wszystkich innych jest z pewnością najpierwsza"46 ${ }^{9}$. Czyż to stwierdzenie artysty, nie jest ukazaniem bliskości a nawet symbiozy sztuki artystycznej i sztuki myślenia? Tej ostatniej jednak przyznaje wyraźny prymat.

\section{Summary \\ Ratio in Art}

Art not only arouses emotion and aesthetic experience through the beauty. It is also a message of different content. It stimulates reflection and contemplation at the same time. It is also a testimony of the time and the artist himself. Sacrum has a cognitive, didactic but also mystical and eschatological role. To effectively assist in meeting the God, it should merge the triad: fides, ratio and ars.

Słowa kluczowe: ratio, mądrość, słowo, sztuka, fides, symbolika, ikonografia

Key words: ratio, wisdom, word, art, fides, symbolism, iconography

Henryk Nadrowski, dr hab. - teolog sztuki, ale także dr historii sztuki, już od lat seminaryjnych zajmuje się problematyką wychowawczych, teologicznych, liturgicznych i duszpasterskich aspektów różnych przejawów twórczości artystycznej.

45 J. M u s i a ł, Sacrum wieńczy dzieło, „Znak” 1983 nr 4 (341), s. 723.

46 J. W olf, Wybrańcy sztuki, Państwowy Instytut Wydawniczy, Warszawa 1982, s. 38. 
W ponad 300 publikacjach najwięcej uwagi poświęca jej kontekstowi posoborowemu. Przed laty związany z ATK, potem z Uniwersytetem Adama Mickiewicza w Poznaniu. Współpracuje z różnymi redakcjami oraz jest recenzentem i konsultantem aranżacji obiektów sakralnych.

\section{Bibliografia}

Arendt H., Roztargnienie filozofa, „Znak” $1981 \mathrm{nr} 9$ (327), s. 1268.

Balthasar H. U., Epilog, Wydawnictwo WAM, Kraków 2010, s. 54.

Białostocki J., Sztuka i myśl humanistyczna. Studia z dziejów sztuki i myśli o sztuce, Państwowy Instytut Wydawniczy, Warszawa 1966, s. 155n.

Bolewski J., Inicjacja Mądrości. Dla życia, duchowości, teologii, Wydawnictwo Święty Wojciech, Poznań 2012, s. 7.

Bracha K., Teolog - intelektualista i duszpasterz w spoleczeństwie średniowiecznym, w: W. Fałkowski (red.), Kolory i struktury Średniowiecza, Wydawnictwo DIG, Warszawa 2004, s. 138.

Brown P., Narodziny zachodniego chrześcijaństwa, Wydawnictwo Krąg, Warszawa 2000, s. 55;

Budowa i konserwacja kościołów. Poradnik - Vademecum. Praca zbiorowa, Rada Prymasowska Budowy Kościołów, Warszawa 1981, ss. 335.

Cammilleri R., Wielka księga Świętych Patronów, Wydawnictwo Jedność, Kielce 2001, ss. 536.

Cieślińska N. (red.), Sacrum i sztuka, Wydawnictwo Znak, Kraków 1989.

Dodds E. R., Pogaństwo i chrześcijaństwo w epoce niepokoju, Wydawnictwo Homini S.C., Kraków 2004, s. 98.

Eco U., Historia piękna, Dom Wydawniczy Rebis, Poznań 2005, s. 12.

Filipiak M., Homo communicans. Wprowadzenie do teorii masowego komunikowania, Wydawnictwo Uniwersytetu Marii Curie-Skłodowskiej, Lublin 2003, s. 119.

Goecke-Seischab M. L. Harz, F., Chodź, pokażę Ci kościót. Poradnik dla rodziców, wychowawców, nauczycieli, Instytut Wydawniczy Pax, Warszawa 2003, s. 7.

Jan Paweł II, Fides et ratio, Encyklika podpisana 14 września 1998, Kolekcja Hachette, Warszawa 2007.

Jan Paweł II, List do artystów, Księgarnia Świętego Wojciecha, Poznań 2007, s. 7, 8.

Kołakowski L., Jezus ośmieszony. Esej apologetyczny i sceptyczny. Wydawnictwo Znak, Kraków 2014, s. 35, 47, 76, 78.

Kongregacja Nauki Wiary, Deklaracja „Dominus Iesus“. Tekst i komentarze, Wprowadzenie: kard. Joseph Ratzinger, Pallottinum, Poznań 2006. 
Kowalski K., Europa: mity, modele, symbole, Międzynarodowe Centrum Kultury, Kraków 2002, s. 145-166.

Krąpiec M. A., Chrześcijaństwo - wspólne dobro Europy, „Znak” 191 nr 9 (327), s. $1164 / 5$.

Lanzi F. i G., Jak rozpoznać świętych i patronów w sztuce i wyobrażeniach ludowych, Wydawnictwo Jedność, Kielce 2004, ss. 239.

Ławniczak W., Teoretyczne podstawy interpretacji dziet sztuki plastycznej, Wydawnictwo Naukowe UAM, Poznań 1975, s. 3n.

Marecki J., Rotter L., Jak czytać wizerunki świętych. Leksykon atrybutów i symboli hagiograficznych, Universitas, Kraków 2009, s. 14-21.

May G., Die andere Hierarchie, Verlag Franz Schmitt, Siegburg 1997, s. 71-90, 107-111.

Musiał J., Sacrum wieńczy dzieło, „Znak” $1983 \mathrm{nr} 4$ (341), s. 723.

Nadrowski H., Język wiary a wyraz sztuki, w: P. Bortkiewicz, S. Mikołajczak, M. Rybka (red.), Język religijny dawniej i dziś (w kontekście teologicznym i kulturowym), t. 5. Materiały z konferencji, Gniezno 22-24 września 2008, Wydawnictwo Poznańskie Studia Polonistyczne, Poznań 2008, s. 141.

Nadrowski H., Relacje „fides”, „ratio” $i$,,ars” w zabytkowym kościele. „Zeszyty Naukowe Politechniki Białostockiej, Budownictwo", 2006 nr 30, s. 289-306.

Ostrzołek W., Moje witrażowe Stegny, w: T. Mierzwiński (red.), Witraże stegieńskie Wiktora Ostrzołka. Miłosierdzie Boże w historii zbawienia. Wydawnictwo Księży Marianów, Warszawa 2003, s. 13.

Pasierb J. St., Ochrona zabytków sztuki kościelnej, przygotował: Jerzy Żmudziński, Biblioteka Towarzystwa Opieki nad Zabytkami, Warszawa 1995, ss. 242, ilustr. 81.

Penrice J., Młodość i chrześcijaństwo czyli zrozumieć swoją wiarę, Wydawnictwo WAM, Kraków 1998.

Poprzęcka M., Galeria. Sztuka patrzenia, Wydawnictwo Stentor, Warszawa 2003, s. 9.

Porębski M., Sztuka a informacja, Wydawnictwo Literackie, Kraków, Wrocław 1986, s. 174-176, 186/7.

Ratzinger J., Opera omnia, t. XI Teologia liturgii, Wydawnictwo KUL, Lublin 2012, s. 196.

Ravasi G., Święte Księgi. Jak czytać i rozumieć Pismo Święte, Wydawnictwo Esprit, Kraków 2015, s. 6, por. s. 97-103.

Rouba B. J., Pielęgnacja świątyni. Książka dla księży, Toruńskie Wydawnictwo Diecezjalne, Toruń 2000. 
Świerzawski W. (red.), Sztuka w liturgii, Zawichost, Kraków, Sandomierz 2013, ss. 511.

Taylor R., Przewodnik po symbolice kościoła, Klub dla Ciebie, Warszawa 2006, s. 11. Waźbiński Z., Ut Ars Natura, Ut Natura Ars, Wydawnictwo UMK, Toruń 2000, s. 9, 168-179. 227-247.

Wincenty z Lerynu, Pamiętnik Commonitorium, Uniwersytet im. Adama Mickiewicza, Poznań 2002 (reprint z 1928 roku), s. 48, 40.

Wit Z., Podstawy liturgiczno-prawne miejsca celebracji odnowionej liturgii, w: W. Świerzawski (red.), Sztuka w liturgii, Zawichost, Kraków, Sandomierz 2013, s. 346-349.

Wolf J., Wybrańcy sztuki, Państwowy Instytut Wydawniczy, Warszawa 1982, s. 38. Zieliński Ch., Sztuka sakralna. Co należy wiedzieć o budowie, urzadzeniu, wyposażeniu, ozdobie i konserwacji Domu Bożego, Księgarnia św. Wojciecha, Poznań 1960, ss. XXXVI, 1004. 